СМ. С. Хміль, С. В. Хміль, Н. Я. Чудійович, А. С. Хміль-Досвальд, Л. М. Маланчук

Тернопільський національний медичний університет ілені І. Я. Горбачевсъкого МОЗ України

Медичний центр «Клініка професора Стефана Хліля»

\title{
ЕФЕКТИВНІСТЬ ВИКОРИСТАННЯ ВІТАМІНУ D У КОМПЛЕКСНОМУ ЛІКУВАННІ БЕЗПЛІДДЯ У ЖІНОК ІЗ СИНДРОМОМ ПОЛІКІСТОЗНИХ ЯЄЧНИКІВ
}

Проблема безплідного шлюбу залишається актуальною в сучасному акушерстві, гінекології та репродуктології. Синдром полікістозних яєчників $є$ однією з найчастіших причин ановуляторного безпліддя, що являє собою найпоширенішу ендокринну патологію у жінок репродуктивного віку, асоційовану з безпліддям, що характеризується гіперандрогенією, морфологічно кістознозміненими яєчниками та порушенням менструального циклу. У статті коротко представлено сучасні погляди на діагностику та лікування даної ендокринопатії. Висвітлено численні дані сучасної вітчизняної та зарубіжної літератури щодо ефективності використання вітаміну D у комплексному лікуванні та прегравідарній підготовці жінок із синдромом полікістозних яєчників. Доведено його зв'язок із фрертильністю, важливу роль у патогенезі синдрому полікістозних яєчників, взаємозв'язок з метаболічними та репродуктивними порушеннями, роль у нормальному перебігу вагітності.

Ключові слова: вітамін D; синдром полікістозних яєчників; безпліддя; метаболічні порушення; допоміжні репродуктивні технології.

ЭФФЕКТИВНОСТЬ ИСПОЛЬЗОВАНИЯ ВИТАМИНА D В КОМПЛЕКСНОМ ЛЕЧЕНИИ БЕСПЛОДИЯ У ЖЕНЩИН С СИНДРОМОМ ПОЛИКИСтОзНЫХ ЯИЧнИкОВ

Проблема бесплодного брака остается актуальной в современном акушерстве, гинекологии и репродуктологии. Синдром поликистозных яичников является одной из самых частых причин ановуляторного бесплодия, представляет собой самую распространенную эндокринную патологию у женщин репродуктивного возраста, ассоциированную с бесплодием, характеризующуюся гиперандрогенией, морфологически кистозноизмененными яичниками и нарушением менструального цикла. В статье кратко представлены современные взгляды на диагностику и лечение данной эндокринопатии. Выделены многочисленные данные современной отечественной и зарубежной литературы об эффективности использования витамина D в комплексном лечении и прегравидарной подготовке женщин с синдромом поликистозных яичников. Доказана его связь с фертильностью, важная роль в патогенезе синдрома поликистозных яичников, связь с метаболическими и репродуктивными нарушениями, роль в нормальном течении беременности.

Ключевые слова: витамин D; синдром поликистозных яичников; бесплодие; метаболические нарушения; вспомогательные репродуктивные технологии.

EFFICIENCY OF VITAMIN D USING IN COMPLEX TREATMENT OF INFERTILITY IN WOMEN WITH POLYCYSTIC OVARY SYNDROME

The problem of infertile marriage remains relevant in modern obstetrics, gynecology and reproductive medicine. Polycystic ovary syndrome is one of the most common causes of anovulatory infertility, which is the most common endocrine pathology in women of reproductive age associated with infertility, characterized by hyperandrogenism, morphologically cystic-modified ovaries, and menstrual disorders. The article briefly presents modern views on the diagnostic and treatment of this endocrinopathy. The numerous data of modern domestic and foreign literature on the effectiveness of vitamin D using in complex treatment and pregravid preparation of women with polycystic ovary syndrome are highlighted. It is proved its connection with fertility, an important role in the pathogenesis of PCOS, the relationship with metabolic and reproductive disorders, the role in the normal course of pregnancy.

Key words: vitamin D; polycystic ovary syndrome; infertility; metabolic disorders; assisted reproductive technologies.

Безпліддя є складною медико-соціальною проблемою, яка вже протягом багатьох років є однією з найбільш актуальних у сучасному акушерстві, гінекології та репродуктології [1]. Відповідно до визначення ВОО3, безплідною вважають подружню пару, у якої є бажання мати дитину, активні статеві стосунки без використання контрацептивів, проте вагітність не настає протягом одного року в жінки віком до 35 років та протягом півроку в жінки, старшої за 35 років [2]. Все більша кількість подружніх пар вдається до використання можливостей допоміжних репродуктивних технологій при лікуванні безпліддя, які на сьогодні $€$ найефрективнішим методом у лікуванні даної патології. Допоміжні репродуктивні технології (ДРТ) являють собою комплекс методик, спрямованих на подолання непліддя, за допомогою яких окремі чи всі етапи дозрівання яйцеклітин, їх запліднення, розвиток ембріонів до їх транссреру в порожнину матки відбуваються в умовах «іn vitro», тобто поза організмом жінки [2-4]. За даними статистики, представленими УАРМ, за період із 2017 р. по 2018 р. в Україні було зареєстровано 38168 випадків жіночого безпліддя (що складає 77,72 \% від структури загальних випадків чоловічого та жіночого безпліддя) та 10945 випадків чоловічого безпліддя $(22,23 \%)$. За даними різних авторів, на жіноче безпліддя припадає близько $60 \%$ усіх випадків, частка чоловічого непліддя складає 40 \%. У структурі безплідного шлюбу ендокринне безпліддя займає вагоме місце, оскільки ця форма непліддя частіше буває первинною та характеризується поліморфністю клінічних та 
лабораторних проявів. Спільною ознакою для всіх фрорм ендокринного безпліддя $€$ ановуляція [5]. На його частку припадає близько 40 \% серед усіх фрорм жіночого непліддя [6]. Синдром полікістозних яєчників є однією з найчастіших причин ановуляторного безпліддя $[7,8]$.

Синдром полікістозних яєчників (СПКЯ) - найпоширеніша ендокринна патологія у жінок репродуктивного віку, асоційована з безпліддям, що характеризується гіперандрогенією, морфологічно кістознозміненими яєчниками та порушенням менструального циклу. За даними багатьох досліджень, у світі синдром полікістозних яєчників діагностують близько в 7 \% жінок репродуктивного віку [9]. Все більша кількість наукових праць спрямована на вивчення даної патології. Проте етіологія та патогенез СПкя до кінця залишаються не вивченими. У літературі наявні дані про генетичну схильність ризику розвитку СПкЯ $[10,11]$.

Патофрізіологія синдрому полікістозних яєчників включає первинні дефекти у функціонуванні гіпоталамо-гіпофрізарно-яєчникової системи, секреції і дії інсуліну та фрункціонуванні яєчників $[12,13]$. Хоча причина СПкЯ до кінця не відома, проте існує взаємозв'язок між виникненням даної ендокринопатії, інсулінорезистентністю та ожирінням. IHсулін впливає на регуляцію функції яєчників, в результаті чого на надлишок інсуліну яєчники реагують підвищеним виробленням андрогенів, що призводить до ановуляції [12]. Багато дослідників вважають, що у виникненні синдрому полікістозних яєчників ключову роль відіграють уроджені аномалії стероїдогенезу. Синдром пов'язаний із постійними швидкими імпульсами гонадотропін-рилізинг гормону, надлишком лютеїнізуючого гормону та недостатньою секрецією фролікулостимулюючого гормону, що призводять до надлишкового синтезу андрогенів у яєчниках, як наслідок, виникають овуляторні порушення [14]. Оскільки стероїдогенез у яєчниках потребує стимуляції гонадотропінами, підвищена секреція лютеїнізуючого гормону є ключовим фрактором у виникненні гіперандрогенії, порушенні нормального фолікулогенезу з розвитком множинних кістознозмінених фолікулів, гіперплазії тека клітин та строми яєчника при синдромі полікістозних яєчників [15]. Наслідком є зниження секреції фролікулостимулюючого гормону, в результаті якого відбувається порушення секреції цитохрому P450, що бере участь у перетворенні андрогенів в естрогени у жировій тканині [16-18]. Ці порушення спричиняють виникнення гормонального дисбалансу, що сприяє підвищенню концентрації андрогенів над естрогенами. Як відомо, для більшості жінок із СПкЯ характерна інсулінорезистентність, в результаті чого виникає компенсаторна гіперінсулінемія, яка сприяє підвищеному виробленню андрогенів в яєчниках та надниркових залозах, що підвищує біодоступність андрогенів за рахунок зниження концентрації глобуліну, що зв'язує статеві гормони [19-22]. Важливе місце в патогенезі СПКЯ відіграє ожиріння, при якому порушується толерантність до глюкози за діабетичним типом, розвиваються інсулінорезистентність та компенсаторна гіперінсулінемія. В результаті цих метаболічних порушень посилюється синтез андрогенів в адипоцитах [23].

Клінічна картина даного захворювання є дуже різноманітною. Основними клінічними симптомами є порушення менструального циклу за типом олігоменореї, первинної чи вторинної аменореї, хронічної ановуляції, рідше дисфрункціональних маткових кровотеч. Гіперандрогенія у жінок із СПКЯ проявляється у вигляді гірсутизму, себореї, алопеції чи акне [23]. Для жінок із склерополікістозом характерними є безпліддя та репродуктивні втрати. Жінки із синдромом полікістозних яєчників мають підвищений ризик виникнення ускладнень вагітносі, таких як гестаційний цукровий діабет та пов'язану з ним макросомію плода, гіпертензивні розлади під час вагітності, виникнення прееклампсії. Невиношування вагітності, що частіше проявляється ранніми мимовільними викиднями, та перинатальна смертність збільшуються при даній ендокринопатії, що опосередковано пов'язано з метаболічними порушеннями (ожирінням, порушенням метаболізму глюкози) та порушеннями маткового кровотоку [24-29]. Жінкам із склерополікістозом важливу увагу потрібно приділити метаболічним порушенням: надлишковій масі, абдомінальному ожирінню, порушенню вуглеводного та ліпідного обміну [30]. Серед порушень вуглеводного обміну, що спостерігаються при полікістозі, характерними $€$ інсулінорезистентність, гіперінсулінемія, гіперглікемія, порушення толерантності до глюкози та високий ризик розвитку цукрового діабету 2 типу [31, 32]. Доведено, що дисліпідемія, яка є характерною при СПКЯ, призводить до ризику виникнення серцево-судинних захворювань (атеросклероз, стенокардія, ішемічна хвороба серця, інфраркт міокарда) [33]. За даними літератури, у 75-91 \% хворих на СПКя зустрічається гіперплазія ендометрія [34]. Гіперпластичні процеси ендометрія у жінок із СПКЯ виникають у результаті хронічної ановуляції, спричиненої гіперестрогенією. Отже, СПКЯ є значним фрактором у ризику виникнення не лише гіперплазії ендометрія, а й сприяють розвитку злоякісної патології ендометрія [34-36].

Діагностика синдрому полікістозних яєчників базується на основних критеріях даного синдрому, прийнятих Роттердамським консенсусом у 2003 р., що включає: хронічну ановуляцію та порушення менструального циклу; гіперандрогенію (клінічну та/або біохімічну); морсрологічно кістознозмінені яєчники, підтверджені даними УЗД. Наявність щонайменше двох 3 вищеперелічених симптомів дає змогу верифрікувати даний діагноз [37]

Терапія жінок із СПкЯ потребує комплексного та індивідуального підходу. В основному лікування пацієнтів із даною патологією спрямоване на нормалізацію метаболічних та ліпідних порушень, відновлення репродуктивної функції за рахунок відновлення менструального циклу та овуляції, попередження виникнення серцево-судинних захворювань і ускладнень перебігу та виношування вагітності.

Протягом останніх десятиліть інтенсивно вивчається вплив вітаміну D на фертильність жінки. Велика кількість даних свідчить про сприятливий вплив вітаміну D на метаболічні та гормональні порушення при синдромі полікістозних яєчників та ефеективність лікування безпліддя у програмах допоміжних репродуктивних технологій [38].

Вітамін D належить до групи жиророзчинних вітамінів, який міститься лише в невеликій кількості у продуктах харчування. Добре відома його роль у гомеостазі кальцію та мінералізації кісток [39-41]. Найпоширенішими його формами є вітамін D2 (ергокальциферол) та вітамін D3 (холекальциферол) [42, 43]. Ергокальциферол утворюється із рослинного попередника (провітаміну D2) - ергостерину, в організм людини надходить лише з їжею, а холекальциферол походить із 7-дегідрохолестерину. Необхідною умовою для його синтезування в епідермісі 
$€$ наявність достатньої інсоляції [44, 45]. Вітамін D, отриманий із продуктів харчування у вигляді харчових добавок, а також утворений при інсоляції, біологічно інертний. Для їх перетворення в гормонально активну фрорму вітаміну D 1,25(OH)2D3 (кальцитріол), в організмі повинно пройти 2 процеси гідроксилювання. У печінці вітамін D2 та вітамін D3 перетворюються в 25-гідроксивітамін D (25(OH)D), найбільш поширену форму сироваткового вітаміну D. Концентрація 25(OH) D в сироватці крові та плазмі $є$ найкращим індикатором вмісту вітаміну D. Оптимальна концентрація 25-гідроксивітаміну D у сироватці крові має перевищувати 30 нг/мл, а рівень його в крові, нижчий за 20 нг/мл, має розцінюватись як «десріцит» [38, 46, 47]. Дія кальцитріолу опосередкована зв'язуванням зі специфрічним ядерним рецептором (VDR), який при активації запускає множинн геномні ефекти. Кальцитріол також може зв'язуватись із рецепторами плазматичних мембран, медіюючи деякі негеномні ефекти [48].VDR узгоджено взаємодіє з рецептором ретиноїду $\mathrm{X}(\mathrm{RXR})$, в результаті чого утворюється гетеродимер та взаємодіє з іншими кофакторами, включаючи супресори та активатори, які регулюють його фрункцію [49]. Гетеродимер VDR-RXR зв'язується з вітаміном D чутливими елементами, що розташовані в промоторних ділянках органів-мішеней, як наслідок, регулює їх транскрипцію [48].

Основною дією вітаміну $\mathrm{D} \in$ мінералізація кісток за рахунок поглинання кальцію та фоосфору в тонкому кишечнику. Проте поширення специфічних рецепторів VDR в організмі людини, які містяться майже у всіх тканинах підтверджує важливу роль вітаміну D у нормальному фрункціонуванні різних систем та органів і його вплив на репродуктивну фрункцію [50-52].

Особливу увагу привертає використання вітаміну D в лікуванні безпліддя, асоційованого із синдромом полікістозних яєчників [38, 48].

На фрармацевтичному ринку $є$ широкий вибір препаратів вітаміну D, як водних, так і олійних розчинів. Широкого застосування у лікувальній практиці в країнах Європи набув препарат Eu Tylia D3 (виробник E. Vitalgroup, Італія), це таблетки, що диспергуються та містять у своєму складі 50 мкг вітаміну D, що відповідає 2000 ОД холекальциферолу. Перевагами Eu Tylia D3 $є$ зручність у використанні (сублінгвально) по одній таблетці один раз на добу.

У дослідженнях наявні дані про те, що дефріцит вітаміну D посилює прояви склерополікістозу. В сучасній літературі чітко показано взаємозв'язок десріциту вітаміну $\mathrm{D}$ із метаболічними та репродуктивними порушеннями, характерними для жінок із СПКЯ, що, в свою чергу, підтверджує його вплив на патогенез даного захворювання. Як відомо, ключовими елементами в патогенезі СПкЯ є порушення вуглеводного обміну, а саме гіперінсулінемія та інсулінорезистентність [53, 54]. Існують численні дані про вплив вітаміну D на вуглеводний обмін. Його недостатність $€$ фрактором ризику порушення толерантності до глюкози, виникнення інсулінорезистентності та цукрового діабету 2 типу. Доведено, що вітамін D посилює дію інсуліну шляхом контролювання експресії рецептора інсуліну та підвищує чутливість до інсуліну для транспорту глюкози [55]. Наявні дані про його вплив на внутрішньо- та позаклітинний кальцій, що є ключовим для нормального функціонування інсуліночутливих тканин. Доведена його протизапальна дія. Деякі вчені пов'язують знижений рівень 25(OH)D із наслідком хронічного запалення [56]. У сучасній вітчизняній та іноземній літературі наявні дані про те, що ожиріння, яке часто супроводжує жінок із СПКЯ, напряму пов'язане з дефіцитом вітаміну D в організмі, що в численних дослідженнях підтверджується зниженою концентрацією 25-гідроксивітаміну D $(25(\mathrm{OH}) \mathrm{D})$ у жінок із метаболічними порушеннями на фроні склерополікістозу порівняно з контрольними групами $[57,58]$. Десріцит вітаміну D сприяє підвищенню рівнів концентрації паратиреоїдного гормону в сироватці крові, який асоційований зі зниженням чутливості до інсуліну [59].

Протягом останнього часу з'явилось все більше досліджень про вплив препаратів вітаміну D на овуляторну диссункцію, андрогенний статус та результати ЕКЗ, перебіг вагітності у жінок із СПкЯ.

Розвиток гіперандрогенії на тлі Спкя опосередкований зі зниженням вироблення глобуліну, що зв'язує статеві гормони (ГЗСГ) в печінці. Характерна для жінок із СПкя гіперінсулінемія сприяє порушенню синтезу ГЗСГ, в результаті чого спостерігається зниження концентрації даного глобуліну в жінок із даною ендокринопатією тією чи іншою мірою. Щоденне приймання холекальциферолу щонайменше протягом 3-х місяців сприяє підвищенню концентрації ГЗСГ у сироватці крові. Крім того, на фроні прегравідарної підготовки вітаміном D спостерігається нормалізація співвідношення гонадотропінів (ЛГ/ ФСГ) та нормалізація толерантності до глюкози разом із зниженням рівня інсуліну в крові. В результаті спостерігається нормалізація метаболічних порушень і, як наслідок, нормалізація маси тіла у жінок із СПКя [60, 61]. Karolina Lagowska (2018р.) у своїй роботі чітко висвітлює взаємозв'язок дефіциту вітаміну D із порушеннями менструального циклу за типом дис-, оліго- чи аменореї [62]. Протягом останніх років інтенсивно вивчається взаємозв'язок вітаміну D із несприятливими наслідками вагітності. Як відомо, для плода єдиним джерелом надходження даного вітаміну є вагітна жінка, яка забезпечує нормальну підтримку потреб у мінералізації його скелета протягом його внутрішньоутробного розвитку. Доведено, що протягом вагітності відбувається фрізіологічне підвищення гідроксивітаміну D, особливо це спостерігається в III триместрі. При дефріциті вітаміну D під час вагітності можливий ризик виникнення серйозних ускладнень, особливо другої половини вагітності, а саме розвиток прееклампсії, гестаційного діабету, передчасних пологів та родорозрішення шляхом операції кесаревого розтину $[45,63]$.

Роль вітаміну D в ефективності результатів екстракорпорального запліднення була розглянута в множинних рандомізованих та контрольованих дослідженнях. Проте вплив його на результати ЕКЗ до кінця залишається не з'ясованим.

У роботі Ozkan S., Jindal S., Greenseid K. et al. висвітлено потенційно позитивний ефект приймання вітаміну D на результати програм ЕКЗ. Доведено, що жінки з нормальним рівнем вітаміну D мали вищу частоту настання вагітності порівняно $з$ жінками із його дефріцитом [64].

Вивчаючи вплив використання вітаміну D на фертильність жінок, Lerchbaum E., Rabe T. (2014р.) відмітили, що жінки з рівнем вітаміну D>30 нг /мл мали вищий показник успішності циклів ЕКЗ, що пов'язувалось із його впливом на рецептивність ендометрія [65]. 
Pagliardini L., Paola V., Molgora M. et al. (2015 р.) у своїй роботі висвітлили, що у більшості жінок, які звертаються в центри репродуктивних технологій для лікування безпліддя, спостерігається десріцит вітаміну D. Цим підтверджується його вплив на репродуктивний потенціал жінки [66]

Zhao J., Liu S., Wang Y. та ін. довели, що добавка вітаміну D може нормалізувати рівні сироваткового вітаміну D y безплідних жінок із СПКЯ та інсулінорезистентністю, що приводить до покращення якості ембріонів та значно вищої частоти настання клінічної вагітності [67].

Alzaidi M. M. et al. (2017 р.) стверджують, що все ж немає переконливих доказів того, що існує причинно-наслідковий зв'язок між вітаміном D та фрертильністю [68].

Численні дослідження висвітлюють взаємозв'язок вітаміну D 3 фертильністю жінки. Дані досліджень показують, що вітамін D відіграє ключову роль у патогенезі
СПКЯ та впливає на есективність результатів ЕКЗ у жінок із даною патологією. Крім того, доведено його вплив на деякі метаболічні й репродуктивні порушення та перебіг вагітності. На сьогодні існує безліч дискусій стосовно механізму його впливу на репродуктивну систему жінки та оптимального його дозування у лікуванні жінок із безпліддям, асоційованим зі склерополікістозом, що в подальшому потребує ширшого вивчення.

ПЕРСПЕКТИВИ ПОДАЛЬШИХ ДОСЛІДЖЕНЬ. Перспективою подальших досліджень буде вивчення зв'язку концентрації вітаміну D в сироватці крові з результатами ЕКЗ у жінок, які проходять лікування безпліддя на фроні СПКЯ. Детального вивчення потребує підбір необхідної добової дози для ефрективності лікування проявів СПкЯ, успішності результатів ЕКЗ та нормального перебігу вагітності у жінок із даною патологією.

15. Robert L. R. The pathogenesis of polycystic ovary syndrome (PCOS): The hypothesis of PCOS as functional ovarian hyperandrogenism revisited / L. R. Robert, A. E. David // Endocr. Rev. - 2016. - Vol. 37 (5). - P. 467-520.

16. Qin K. N. Role of cytochrome P450c17 in polycystic ovary syndrome / N. K. Qin, R. L. Rosenfield // Mollecular and Cellular Enocr. - 1998. - Vol. 145 (1-2). - P. 111-121.

17. Genetics of PCOS: A systematic bioinformatics approach to unveil the proteins responsible for PCOS / P. K. Panda, R. Rane, R. Ravichandran [et al.] // Genomics Data. - 2016. Vol. 8. - P. 52-60.

18. Maggofin D. A. Ovarian enzyme activities in women with polycystic ovary syndrome / D. A. Maggofin // Fertil and Steril. - 2006. - Vol. 86 (1). - P. 9-11.

19. Deswal R. Sex hormone binding globulin - an important biomarker for predicting PCOS risk: A systematic review and meta-analysis / R. Deswal, A. Yadav, A. S. Dang // Syst. Biol. Reprod. Med. - 2018. - Vol. 64 (1). - P. 12-24.

20. Mehrabian F. Can Sex-hormone binding globulin considered as a predictor of response to pharmacological treatment in women with polycystic ovary syndrome? / F. Mehrabian, M. Afghahi // Int. J. Prev. Med. - 2013. - Vol. 4 (10). - P. 1169-1174.

21. Sex hormone-binding globulin genetic variation: Associations with type 2 diabetes mellitus and polycystic ovary syndrome / C. Chen, J. C. Smothers, A. Lange [et al.] // MinervaEndocrinol. - 2010. - Vol. 35 (4). - P. 271-280.

22. The biological variation of testosterone and sex hormonebinding globulin (SHBG) in polycystic ovarian syndrome: implications for SHBG as a surrogate marker of insulin resistance / V. Jayagopal, E. S. Kilpatrick, P. E. Jennings [et al.] // JCEM. - 2003. - Vol. 88 (4). - P. 1528-1533.

23. Синдром поликистозных яичников: особенности диагностики // И. Б. Решетников, З. А. Нестеренко, И. А. Мацнева [и др.] // Молодой ученый. - 2016. - № 26 (2). - С. 38-41.

24. Melatonin and its correlation with testosterone in polycystic ovarian syndrome / P. Jain, M. Jain, C. Haldar [et al.] // J. Human Reprod Sci. - 2013. - Vol. 6 (4). - P. 253-258.

25. Herbal medicine for the management of polycystic ovary syndrome (PCOS) and associated oligo/amenorrhoea and hyperandrogenism; a review of the laboratory evidence for effects with corroborative clinical findings / S. Arentz, J. A. Abbot, C. A. Smith [et al.] // BMC Complement Altern Med. - 2014. Vol. 14. - P. 511. doi: 10.1186/1472-6882-14-511.

26. Rosenfield R. L. The polycystic ovary morphologypolycystic ovary syndrome spectrum / R. L. Rosenfiel // 
J. Pediatr. Adolesc. Gynecol. - 2015. - Vol. 28 (6). - P. 412-419. 27. Serum chemerin level in women with PCOS and its relation with the risk of spontaneous abortion / X. Yang, X. Quan, Y. Lan [et al.] // Gynecol. Endocrinol, - 2018. - Vol. 34 (10). P. 864-867.

28. Pleiotropic roles of melatonin in endometriosis, recurrent spontaneous abortion, and polycystic ovary syndrome / H. L. Yang, W. J. Zhou, C. J. Gu // Am. J. Reprodlmmunol. 2018. - Vol. 80 (1). - P. e12839. doi: 10.1111/aji.12839.

29. Григорян О. Р. Синдром поликистозых яичников - оддаленные риски / О. Р. Григорян, Е. Н. Андреева // Эффрективная фрармакотерапия. Акушерство и гинекология. - 2015. - № 1 (5).

30. Урбанович А. М. Синдром полікістозних яєчників у сьогоденній практиці / А. М. Урбанович // International journal of endocrinology. - 2018. - № 14 (1). - C. 40-45.

31. Bagos P. G. MTHFR C677T polymorphisms in PCOS: a meta-analysis / P. G. Bagos // Mol. Hum. Reprod. - 2009. Vol. 15 (1). - P. 19-26.

32. Архипкіна Т. Л. Особливості гомоцистеїнемії у молодих жінок, хворих на синдром полікістозних яєчників / Т. Л. Архипкіна // Світ медицини та біології. - 2015. - № 1 (48). - C. 9-13.

33. Капшук І. М. Особливості терапії синдрому полікістозних яєчників на фроні надлишкової маси тіла // І. М. Капшук. - 2015. - № 5 (25). - С. 1-26.

34. Гиперпластические процессы эндометрия: особенности клиники и терапии / И. Сидорова, А. Унанян, Р. Власов [и др.] // Врач. - 2011. - № 6. - С. 58-60.

35. Mutter G. Benign Endometrial Hyperplasia Sequence and Endometrial Intraepithelial Neoplasia / G. Mutter, R. Zaino, J. Baak. // Int. J. Gynecolog. Patholog,. - 2007. - Vol. 26 (2). P. 103-114.

36. Стрижаков А. Н. Доброкачественные заболевания матки / А. Н. Стрижаков, А. И. Давидов. - М. : ГЕОТАР-Медиа, 2011.

37. The Rotterdam ESHRE/ASRM-Sponsored PCOS consensus workshop group. Revised 2003 consensus on diagnostic criteria and long-term health risks related to polycystic ovary syndrome (PCOS) // Hum Reprod. - 2004. - Vol. 19 (1) - P. 41-47.

38. Vitamin D and aspects of female fertility / N. Voulgaris, L. Papanastasiou, G. Piaditis [et al.] // Hormone (Athens). 2017. - Vol. 16 (1). - P. 5-21.

39. Irani $M$. Role of vitamin $D$ in ovarian physiology and its implication in reproduction: a systematic review / M. Irani, Z. Merhi // Fertil. Steril. - 2014. - Vol. 102 (2). - P. 460-68.

40. Vitamin D and assisted reproduction: should vitamin $D$ be routinely screened and repleted prior to ART? A systematic review / M. P. Michelle, N. F. Chelsea, M. Shvetha [et al.] // Assist. Reprod. Genet. - 2015. - Vol. 32 (3). - P. 323-335.

41. A pilot study: Effects of decreasing serum insulin with diazoxide on vitamin $D$ levels in obese women with polycystic ovary syndrome / J. E. Nestler, R. E. Reilly, I. Kai [et al.] // Jr. Trans. Am. Clin. Climatol Assoc. - 2012. - Vol. 123. - P. 209-220.

42. Hammami M. Differential effects of vitamin D2 and D3 supplements on 25-hydroxyvitamin D level are dose, sex, and time dependent: a randomized controlled trial / M. Hammami, A. Yusuf // BMC Endocr. Disord. - 2017. - Vol. 17. - P. 12.

43. Effects of high-dose vitamin D2 versus D3 on total and free 25-hydroxyvitamin D and markers of calcium balance / A. Shieh, F. Chun, C. Ma [et al.] // J. Clin. Endocrinol. Metab. 2016. - Vol. 101 (8). - P. 3070-3078.

44. Correlation between follicular fluid levels of SRAGE and vitamin D in women with PCOS / D. Garg, R. Grazi,
G. Lambert-Messerlian, Z. Merhi // J. Assist. Reprod. Genet. 2017. - Vol. 34 (11). - P. 1507-1513.

45. Relevance of vitamin $D$ in reproduction / J. Luk, S. Torrealday, G. N. Perry [et al.] // Hum Reprod. - 2012. - Vol. 27 (10). - P. 3015-3027.

46. Yahya A. A. The effect of vitamin D3 and co-enzyme Q10 supplementation on metabolic biomarkers in women with clomiphene citrate resistant polycystic ovary syndrome // A. A. Yahya, M. K. Abdulridha, B. J. Al-Rubuya // AJPS. - 2018. - Vol. 18 (2). - P. 142-150.

47. Prevalence of vitamin $D$ deficiency in infertile women with polycystic ovarian syndrome and its association with metabolic syndrome - A prospective observational study / K. D. Mogili, R. Karuppusami, S. Thomas [et al.] // EJOG. - 2018. - Vol. 229. - P. 15-19.

48. Vitamin D receptor (VDR)-mediated actions of 1alpha,25(OH)(2)vitamin $D(3)$ : genomic and nongenomic mechanisms / M. R. Haussler, P. W. Jurutka, M. Mizwicki, A. W. Norman // Best Pract. \& Res. Clin. Endocrinol. Metab. 2011. - Vol. 25. - P. 543-559.

49. Rosen C. J. The nonskeletal effects of vitamin D: an Endocrine Society scientific statement / C. J. Rosen, J. S. Adams, D. D. Bikle // Endocr Rev. - 2012. - Vol. 33. P. 456-492.

50 . Vitami $D$ receptor gene polymorphism modify cardiometabolic response to vitamin D supplementation in T2DM patients / N. M. Al-Daghri, A. K. Mohammed, O. S. Al-Attas [et al.] // Scientific Reports. - 2017. - Vol. 7. - P. 8280.

51. Prognostic significance of vitamin D receptor (VDR) gene polymorphism in liver cirrhosis / C. Triantos, I. Aggeletopoulou, M. Kalafateli [et al.] // Scientific Reports. - 2018. - Vol. 8. P. 14065.

52. Regulation of microbiota by vitamin $D$ receptor: a nuclear weapon in metabolic diseases / D. Bakke, I. Chatterjee, A. Agrwal [et al.] // Nuclear Receptor Research. -2018. - Vol. 5. - P. 101377.

53. Strange R. C. Metabolic syndrome: a review of the role of vitamin D in mediating susceptibility and outcome // R. C. Strange, K. E. Shipman, S. Ramachandran // World J. Diabetes. - 2015. - Vol. 6 (7). - P. 896-911.

54. Boucher B. J. Is vitamin D status relevant to metabolic syndrome? / B. J. Boucher // Dermatoendocrinol. - 2012. Vol. 4 (2). - P. 212-224.

55. The role of vitamin $D$ and calcium in type 2 diabetes. A systematic review and meta-analysis / A. G. Pittas, J. Lau, F. B. Hu, B. Dawson-Hughes // J Clin Endocrinol Metab. - 2007. - Vol. 92. - P. 2017-2029.

56. Inflammation and vitamin D: the infection connection / M. Mangin, R. Sinha, K. Fincher // Inflamm. Res. - 2014. Vol. 63 (10). - P. 803-809.

57. Vanlint S. Vitamin D and obesity / S. Vanlnt // Nutrients. - 2013. - Vol. 5 (3). - P. 949-956.

58. Effect of vitamin D supplementation on weight loss, glycemic indices, and lipid profile in obese and overweight women: A clinical trial study / Z. S. Khorsavi, M. Kafeshani, P. Tavasoli [et al.] // Int. J. Prev. Med. - 2018. - Vol. 9. - P. 63. doi: 10.4103/ijpvm.IJPVM_329_15.

59. Vitamin D Status and Its Association with Parathyroid Hormone Concentration in Brazilians / J. S. Martins, M. Palhares, O. Teixeira, M. Ramos // J. Nutr. Metab. - 2017. - Vol. 2017. P. 9056470. doi: 10.1155/2017/9056470.

60. Возможности использования витамина Д3 в лечении бесплодия, обусловленного синдромом поликистозных яичников / Ю. В. Можинская, С. Н. Белик, И. В. Подгорный, Е. Г. Евдокимова // Молодой ученый. - 2016. - № 18 (1). - С. 58-60. 
61. Гафрарова Е. А. Клинико-лабораторные проявления спкЯ в зависимости от фенотипических особенностей и уровня витамина Д в организме / Е. А. Гафарова // Практическая медицина. - 2016. - № 1 (93). - С. 80-84.

62. Lagowska $\mathrm{K}$. The relationship between vitamin D status and the menstrual cycle in young women: a preliminary study / K. Lagowska // Nutrients. - 2018. - Vol. 10 (11). - P. pii: E1729. doi: 10.3390/nu10111729.

63. Dovnik A. The association of vitamin D levels with common pregnancy complications / A. Dovnik, F. Mujezinovic // Nutrients. - 2018. - Vol. 10 (7). - P. pii: E867. doi: 10.3390/ nu10070867.

64. Replete vitamin D stores predict reproductive success following in vitro fertilization / S. Ozkan, S. Jindal, K. Greenseid [et al.] // FertilSteril. - 2010. - Vol. 94. - P. 1314-1319.

\section{REFERENCES}

1. Yuzko, O.M., \& Yuzko, T.A. (2009). Podolannia bezpliddia za dopomohoiu reproduktyvnykh tekhnolohii [Overcoming infertility through reproductive technologies] Medychni aspekty zdorovia zhinky - Medical Aspects of Womans Health, 3 (20) [in Ukrainian].

2. Kapustin, E.V., \& Herevych, H.I. (2016). Mistse ta rol dopomizhnykh reproduktyvnykh tekhnolohii (DRT) u likuvanni nepliddia ta zberezhenni fertylnosti [Place and role of assisted reproductive technologies (ART) in the treatment of infertility and fertility preservation]. Akusherstvo. Hinekolohiia. Henetyka - Obstetrics, Gynecology, Genetics, 2 (2), 30-33 [in Ukrainian].

3. Zaliska, O.M., \& Huz, V.S. (2011). Dopomizhni reproduktyvni tekhnolohii u sviti y Ukraini ta yikhni farmako-ekonomichni aspekty [Assistive reproductive technologies in the world and Ukraine and their pharmacoeconomic aspects]. Ratsionalna farmakoterapiia - Rational Pharmacotherapy, 4 (21), 35-37 [in Ukrainian].

4. Yuzko, T.A., Yuzko, O.M., Zhebchuk, A.B., Zakharenko, L.V., Savchuk, L.T., Chemorkina, I.V., \& Vladychenko, K.A. (2014). Istoriia vprovadzhennia dopomizhnykh reproduktyvnykh tekhnolohii pry likuvanni bezliddia na Bukovyni [History of introduction of assisted reproductive technologies in the treatment of infertility in Bukovina]. Bukovynskyi medychnyi visnyk - Bukovyna Medical Bulletin, 1 (69), 229-231 [in Ukrainian].

5. Tyurina, N.A., \& Sayfetdinova, Yu.F. (2014). Prichiny zhenskogo bezplodiya [Causes of female infertility]. Ogarevonline. Klinicheskaya meditsina - Ogarev-online. Clinical Medicine, 12 [in Russian].

6. Manusharova, R.A. (2014). Beslodnyy brak [Infertile marriage]. Effektivnaya farmakoterapiya, Endokrinologiya - Effective Pharmacology, Endocrinology, 1 (9) [in Russian].

7. Guriyev, T.D. (2010). Sindrom polikistoznykh yaichnikov [Polycystic ovary syndrome]. Ausherstvo. Ginekologiya I reproduktsiya - Obstetrics, Gynecology and Reproduction, 4 (2), 10-15 [in Russian]

8. Nazarenko, T.A. (2008). Sindrom polikistoznykh yaichnikov. Sovremennyye podkhody $k$ diagnostike I lecheniyu besplodiya [Polycystic ovary syndrome. Modern approaches to the diagnosis and treatment of infertility]. Moscow: MEDpressinform. [in Russian].

9. Aubuchon, M, \& Legro, R.S. (2011). Polycystic ovary syndrome: Current infertility management. Clin. Obstet. Gynecol., 54 (4), 675-684.

10. Amato, P., \& Simpson, J.L. (2005). The genetics of polycystic ovary syndrome. Best Pract. Res. Clin. Obstet. Gynaecol., 18, 707-718.

11. Givens, J.R. (1988). Familial polycystic ovarian disease. Endocrinol. Metab. Clin. N. Am., 17, 771-783.
65. Lerchbaum E. Vitamin D and female fertility / E. Lerchbaum, T. Rabe // Curr. Opin. Obstet. Gynecol. - 2015. - Vol. 26 (3). - P. 145-150.

66. High prevalence of vitamin D deficiency in infertile women referring for assisted reproduction / L. Pagliardini, V. Paola, M. Molgora, P. Persico [et al.] // Nutrients. - 2015. - Vol. 7 (12). - P. 9972-9984.

67 . Vitamin D improves the outcome of in vitro fertilization (IVF) in infertile women with polycystiv ovary syndrome and insulin resistance / J. Zhao, S. Liu, Y. Wang, P. Wang [et al.] // Minerva Med. - 2019. - Vol. 110 (3). - P. 199-208. doi: 10.23736/ S0026-4806.18.05946-3.

68. Polycystic ovary syndrome and vit D correlation with fertility: rewiev article / M. M. Alzaidi, H. Almir, A. Khormi [et al.] // The Egypt J. of Hosp. Med. - 2017. - Vol. 69 (6). - P. 2627-2631.

12. Diamanti-Kandarakis, E., Kandarakis, H., \& Legro, R.S. (2006). The role of genes and environment in the etiology of PCOS. Endocrine, 30, 19-26.

13. Shannon, M., \& Wang, Y. (2012). Polycystic ovary syndrome: A common but often unrecognized condition. J Midwifery Womens Health, 57, 221-230.

14. McCartney, C.R., \& Marshall, J.C. (2016). Polycystic ovary syndrome. N. Engl. J. Med., 375 (1), 54-64.

15. Robert, L.R., \& David, A.E. (2016). The pathogenesis of polycystic ovary syndrome (PCOS): The hypothesis of PCOS as functional ovarian hyperandrogenism revisited. Endocr. Rev., 37 (5), 467-520.

16. Qin, K.N., \& Rosenfield, R.L. (1998). Role of cytochrome P450c17 in polycystic ovary syndrome. Mollecular and Cellular Enocr, 145 (1-2), 111-121.

17. Panda, P.K., Rane, R., Ravichandran, R., Singh, S., \& Panchal, H. (2016). Genetics of PCOS: A systematic bioinformatics approach to unveil the proteins responsible for PCOS. Genomics Data, 8, 52-60.

18. Maggofin, D.A. (2006). Ovarian enzyme activities in women with polycystic ovary syndrome. Fertil. and Steril., 86 (1), 9-11.

19. Deswal, R*, Yadav, A., \& Dang, A.S. (2018). Sex hormone binding globulin - an important biomarker for predicting PCOS risk: A systematic review and meta-analysis. Syst. Biol. Reprod. Med., 64 (1), 12-24.

20. Mehrabian, F., \& Afghahi, M. (2013). Can sex-hormone binding globulin considered as a predictor of response to pharmacological treatment in women with polycystic ovary syndrome? Int. J. Prev. Med., 4 (10), 1169-1174.

21. Chen, C., Smothers, J.C., Lange, A., Nestler, J.E., Strauss, J.F., Wickham, E.P. (2010). Sex hormone-binding globulin genetic variation: Associations with type 2 diabetes mellitus and polycystic ovary syndrome. Minerva Endocrinol., 35 (4), 271-280.

22. Jayagopal, V., Kilpatrick, E.S., Jennings, P.E., Hepburn, D.A., \& Atkin, S.L. (2003). The biological variation of testosterone and sex hormone-binding globulin (SHBG) in polycystic ovarian syndrome: Implications for SHBG as a surrogate marker of insulin resistance. JCEM, 88 (4), 1528-1533.

23. Reshetnikov, I.B., Nesterenko, Z.A., Matsneva, I.A., Mosolova, M.Yu., Muravyeva, P.A., \& Grabuzdov, A.M. (2016). Sindrom polikistoznykh yaichnikov: osobennosti diagnostiki [Polycystic ovary syndrome: diagnostic features]. Molodoy uchenyy - Young Scientist, 26 (2), 38-41 [in Russian].

24. Jain, P., Jain, M., Haldar, C., Singh, T.B., \& Jain, S. (2013). Melatonin and its correlation with testosterone in polycystic ovarian syndrome. J. Human Reprod. Sci., 6 (4), 253-258. 
25. Arentz, S., Abbott, J.A., Smith, C.A., \& Bensoussan, A. (2014). Herbal medicine for the management of polycystic ovary syndrome (PCOS) and associated oligo/amenorrhoea and hyperandrogenism; a review of the laboratory evidence for effects with corroborative clinical findings. BMC Complement Altern. Med., 14, 511. doi: 10.1186/1472-6882-14-511.

26. Rosenfield, R.L. (2015). The polycystic ovary morphology-polycystic ovary syndrome spectrum. J. Pediatr. Adolesc. Gynecol., 28 (6), 412-419.

27. Yang, X., Quan, X., Lan, Y., Wei, Q., Ye, J., Yin, X., ..., \& Yang Y. (2018). Serum chemerin level in women with PCOS and its relation with the risk of spontaneous abortion. Gynecol. Endocrinol, 34 (10), 864-867.

28. Yang, H.L., Zhou, W.J., Gu, C.J., Meng, Y.H., Shao, J., Li, D.J., \& Li, M.Q. (2018). Pleiotropic roles of melatonin in endometriosis, recurrent spontaneous abortion, and polycystic ovary syndrome. Am. J. Reprod. Immunol., 80 (1), e12839. doi: 10.1111/aji.12839.

29. Grigoryan, O.R., \& Andreyeva, E.N. (2015). Sindrom polikistoznykh yaichnikov-oddalennyye riski [Polycystic ovary syndrome is a ousted risk]. Effektivnaya Farmakoterapiya. Akusherstvo I ginekologyya - Effective pharmacotherapy. Obstetrics and Gynecology, 1 (5) [in Russian].

30. Urbanovych, A.M. (2018). Syndrom polikistoznykh yaiechnykiv u shchodennii praktytsi [Polycystic ovary syndrome in daily practice]. Mezhdunarodnyy zhurnal endokrinologii - International Journal of Endocrinology, 14 (1), 40-45 [in Ukrainian].

31. Bagos, P.G. (2009). MTHFR C677T polymorphisms in PCOS: a meta-analysis. Mol. Hum. Reprod., 15 (1), 19-26.

32. Arkhypkina, T.L. (2015). Osoblyvosti homotsysteinemii u molodykh zhinok khvorykh na syndrom polikistoznykh yaiechnykiv [Peculiarities of homocysteine in young women suffer from polycystic ovarian syndrome]. Svit medytsyny ta biolohii -The World of Medicine and biology, 1 (48), 9-13 [in Ukrainian].

33. Kapshuk, I.M. (2015). Osoblyvosti terapii syndromu polikistoznykh yaiechnykiv na foni nadlyshkovoi masy tila [Special treatment of the syndrome of polycystic eggs on the background of the masses.]. Reproduktyvna endokrynolohiia - Reproductive Endocrinology, 5 (25), 21-26 [in Ukrainian].

34. Sidorova, I., Unanyan, A., Vlasov, R., Evtina, I., \& Karpov, D. (2011). Giperplasticheskiye protsessy endometriya: osobennosti kliniki i terapii [Endometrial hyperplastic processes: clinical features and therapy]. Vrach-Doctor, 6, 58-60 [in Russian].

35. Mutter, G., Zaino, R., \& Baak, J. (2007). Benign endometrial hyperplasia sequence and endometrial intraepithelial neoplasia. Int. J. Gynecolog. Patholog, 26 (2), 103-114.

36. Strizhakov, A.N., \& Davydov, A.I. (2011). Dobrokachestvennyye zabolevaniya matki [Benign deseases of the uterus]. Moscow: GEOTAR-Media.

37. The Rotterdam ESHRE/ASRM-Sponsored PCOS consensus workshop group. Revised 2003 consensus on diagnostic criteria and long-term health risks related to polycystic ovary syndrome (PCOS). (2004). Hum Reprod., 19 (1), 41-47.

38. Voulgaris, N., Papanastasiou, L., Piaditis, G., AngeIousi, A., Kaltsas, G., Mastorakos, G., \& Kassi E. (2017). Vitamin $\mathrm{D}$ and aspects of female fertility. Hormone (Athens), 16 (1), 5-21.

39. Irani, M., \& Merhi, Z. (2014). Role of vitamin D in ovarian physiology and its implication in reproduction: a systematic review. Fertil. Steril., 102 (2), 460-468.

40. Michelle, M.P., Chelsea, N.F., Shvetha, M.Z., Sunni, L.M., James, H., \& Segars, J. (2015). Vitamin D and assisted reproduction: should vitamin $\mathrm{D}$ be routinely screened and repleted prior to ART? Asystematic review. Assist. Reprod. Genet., 32 (3), 323-335.
41. Nestler J.E., Reilly, E.R., Cheang, K.I., Bachmann, L.M., Downs, R.W. (2012). A pilot study: Effects of decreasing serum insulin with diazoxide on vitamin $D$ levels in obese women with polycystic ovary syndrome. Jr. Trans. Am. Clin. Climatol. Assoc., 123, 209-220.

42. Hammami, M., \& Yusuf, A. (2017). Differential effects of vitamin D2 and D3 supplements on 25-hydroxyvitamin D level are dose, sex, and time dependent: a randomized controlled trial. BMC Endocr. Disord., 17.

43. Shieh, A., Chun, F., Ma, C., Witzel, S. Meyer, B., Rafison, B., ..., \& Adams, J. (2016). Effects of high-dose vitamin D2 versus D3 on total and free 25-hydroxyvitamin D and markers of calcium balance. J. Clin. Endocrinol. Metab., 101 (8), 3070-3078.

44. Garg, D., Grazi, R., Lambert-Messerlian, G., \& Merhi, Z. (2017). Correlation between follicular fluid levels of SRAGE and vitamin D in women with PCOS. J. Assist. Reprod. Genet., 34 (11), 1507-1513.

45. Luk, J., Torrealday, S., Perry, G.N., \& Pal L. (2012). Relevance of vitamin D in reproduction. Hum. Reprod., 27 (10), 3015-3027.

46. Yahya, A.A., Abdulridha, M.K., \&Al-Rubuya, B.J. (2018). The effect of vitamin D3 and co-enzyme Q10 supplementation on metabolic biomarkers in women with clomiphene citrate resistant polycystic ovary syndrome. AJPS, 18 (2), 142-150.

47. Mogili, K.D., Karuppusami, R., Thomas, S., Chandy, A., Kamath, M., \& Aleyamma, T.K. (2018). Prevalence of vitamin D deficiency in infertile women with polycystic ovarian syndrome and its association with metabolic syndrome - A prospective observational study. EJOG, 229, 15-19.

48. Haussler, M.R., Jurutka, P.W., Mizwicki, M., \& Norman, A.W. (2011). Vitamin D receptor (VDR)-mediated actions of $1 \alpha, 25(\mathrm{OH})_{2}$ vitamin $\mathrm{D}_{3}$ : genomic and non-genomic mechanisms. Best Pract. Res. Clin. Endocrino.I Metab. - 2011. Vol. 25 (4). P. 543-559. doi: 10.1016/j.beem.2011.05.010.

49. Rosen, C.J., Adams, J.S., \& Bikle, D.D. (2012). The nonskeletal effects of vitamin D: an Endocrine Society scientific statement. Endocr. Rev., 33, 456-492.

50. Al-Daghri, N.M., Mohammed, A.K., Al-Attas, O.S., Ansari, M.G., Wani, K., Hussain, S.D., ..., \& Alokail, M.S. (2017). Vitami D receptor gene polymorphism modify cardiometabolic response to vitamin D supplementation in T2DM patients. Scientific Reports, 7 (1), 8280.

51. Triantos, C., Aggeletopoulou, I., Kalafateli, M., Spantidea, P.I., Vourli, G., Diamantopoulou, G., ..., \& Thomopoulos, K. (2018). Prognostic significance of vitamin D receptor (VDR) gene polymorphism in liver cirrhosis. Sci. Rep. - 8 (1), P. 14065. doi: 10.1038/s41598-018-32482-3.

52. Bakke, D., Chatterjee, I., Agrwal, A., Dai Ya., \& Sun, J. (2018). Regulation of microbiota by vitamin D receptor: a nuclear weapon in metabolic diseases. Nucl. Receptor. Res., 5, P. 101377

53. Strange, R.C., Shipman, K.E., \& Ramachandran, S. (2015). Metabolic syndrome: a review of the role of vitamin $D$ in mediating susceptibility and outcome. World J. Diabetes, 6 (7), 896-911.

54. Boucher, B.J. (2012). Is vitamin D status relevant to metabolic syndrome? Dermatoendocrinol, 4 (2), 212-224.

55. Pittas, A.G., Lau, J., Hu, F.B., \& Dawson-Hughes, B. (2007). The role of vitamin D and calcium in type 2 diabetes. A systematic review and meta-analysis. J. Clin. Endocrinol. Metab., 92, 2017-2029.

56. Mangin, M., Sinha, R., \& Fincher, K. (2014). Inflammation and vitamin D: the infection connection. Inflamm. Res., 63 (10), 803-809.

57. Vanlint, S. (2013). Vitamin D and obesity. Nutrients, 5 (3), 949-956. 
58. Khorsavi, Z.S., Kafeshani, M., Tavasoli, P., Zadeh, A.H., \& Entezari, M.H. (2018). Effect of vitamin D supplementation on weight loss, glycemic indices, and lipid profile in obese and overweight women: A clinical trial study. Int. J. Prev. Med., 9, 63.

59. Martins J. S., Palhares M., Teixeira O., Ramos M. (2017). Vitamin D Status and Its Association with Parathyroid Hormone Concentration in Brazilians. J Nutr Metab, 2017, 9056470.

60. Mozhinskaya, Yu.V., Belik, S.N., Podgornyy, I.V., \& Evdokimova, E.G. (2016). Vozmozhnosti ispolzovaniya vitamina D3 v lechenii besplodiya. Obuslovlennogo sindromom polikistoznykh yaichnikov [The possibility of using vitamin D3 in the treatment of infertility. caused by polycystic ovary syndrome]. Molodoy uchenyy - Young Scientist, 18 (1), 58-60 [in Russian].

61. Gafarovam, E.A. (2016). Kliniko-laboratornyye proyavleniya SPKYa v zavisimosti ot fenotipicheskikh osobennostey urovnya vitamina D v organizme [Clinical and laboratory manifestations of PCOS, depending on the phenotypic characteristics and the level of vitamin D in the org anisme]. Prakticheskaya meditsina - Practical Medicine, 1 (93), 80-84 [in Russian].

62. Lagowska, K. (2018). The relationship between vitamin D status and the menstrual cycle in young women: a preliminary study. Nutrients, 10 (11), pii: E1729. doi: 10.3390/nu10111729.
63. Dovnik, A., \& Mujezinovic, F. (2018). The association of vitamin D levels with common pregnancy complications. Nutrients., 10 (7), E867. doi: 10.3390/nu10070867.

64. Ozkan, S., Jindal, S., Greenseid, K., Shu, J., Zeitlian, G., \& Hickmon, C. (2010). Replete vitamin D stores predict reproductive success following in vitro fertilization. Fertil. Steril., 94, 1314-1319.

65. Lerchbaum, E., \& Rabe, T. (2014). Vitamin D and female fertility. Curr. Opin. Obstet. Gynecol., 26 (3), 145-150.

66. Pagliardini, L., Paola, V., Molgora, M., Persico P., SaIonia A., Vailati S., ..., \& Candiani, M. (2015). High prevalence of vitamin $\mathrm{D}$ deficiency in infertile women referring for assisted reproduction. Nutrients, 7 (12), 9972-9984.

67. Zhao, J., Liu, S., Wang, Y., Wang, P., Qu, D., Liu, M., ..., \& Liu, Y. (2019). Vitamin D improves the outcome of in vitro fertilization (IVF) in infertile women with polycystiv ovary syndrome and insulin resistance. Minerva Med., 110 (3), 199-208. doi: 10.23736/S0026-4806.18.05946-3.

68. Alzaidi, M.M., Almir, H., Khormi, A., Alltaleb, Ya., Muwais, Z., \& Alsaleh, R. (2017). Polycystic ovary syndrome and vit D correlation with fertility: rewiev article. The Egypt J. of Hosp. Med., 69 (6). 